\title{
Evaluation of Bacteriological Quality of Dried Cray Fish (Astacus leptodactylus) Sold at Ogbete Main Market in Enugu Metropolis, Nigeria
}

\author{
Ugwu, Celestina Chibuzo*
}

Department of Applied Microbiology and Brewing, Department of Applied Natural Sciences, Enugu State University of Science and Technology, Nigeria

*Corresponding author

\section{A B S T R A C T}

\section{Keywords}

Dry crayfish, Bacterial load, Prevalence, Bacteria, Food contamination.

\section{Article Info}

Accepted:

24 August 2019 Available Online:

10 September 2019
Cray fish (Astacus leptodactylus) is one of the foods used as a source of protein for both the high- and low- income earners, hence harbor pathogenic bacteria of public health significance. This study is aimed at evaluating the bacteriological quality of dried crayfish (Astacus leptodactylus) sold at Ogbete main market in Enugu metropolis, Nigeria. The two kinds of dry crayfish (Astacus leptodactylus) samples were screened bacteriologically using ten-fold dilution method. A total of sixty(60) dried crayfish samples (30 each for both sample) were collected from different sellers at Ogbete main market, Enugu. Two kinds of crayfish (Orini and Ishekeri) sold in the market were labelled as sample A and sample B. Staphylococcus aureus, Escherichia coli, Bacillus sp and Klebsiella sp were isolated. The mean bacterial load of these organisms ranged from $2.2 \times 10^{4}$ to $2.5 \times 10^{4} \mathrm{cfu} / \mathrm{ml}$ for both fish types. The prevalence rates are as follows: Staphylococcus aureus $30 \%$ and $26.67 \%$, Escherichia coli $20 \%$ and $20 \%$, Bacillus sp $13.33 \%$ and $16.67 \%$ and Klebsiellasp10\% and $13.33 \%$ for both samples respectively. This result suggested that the samples were contaminated with bacteria which have been reported to be pathogenic to humans and animals, hence adequate hygiene must be observed during the collection, processing, transportation and sale of the edible food.

\section{Introduction}

Cray fish (Astacus leptodactylus) is one of the foods used as a source of protein for both the high- and low- income earners. It is a freshwater crustacean resembling small lobsters. Some species are found in brooks and streams where there is running fresh water, while others thrive in swamps, ditches and paddy fields. Fish is known as a low fat, high protein food and usually contains useful fatty acids such as Omega-3 fatty acids which are important for optimal brain and nervous system development (Orogu et al., 2018). Fish constitutes more than $60 \%$ of the protein intake in adults especially in rural areas of 
Nigeria (Adeleye, 1992). Crayfish contains a good amount of vitamin A, C,B6, thiamine, riboflavin (Willard, 2006).It is also rich in sodium, potassium and phosphorous with good amount of iron, zinc, copper and manganese(Orogu et al., 2018). Crayfish is preserved from bacterial deterioration by drying, smoking, freezing, chilling and banning, but drying is the commonest way used to prolong the shell life of the products by reducing the water content thereby protecting the products (Orogu et al., 2018). The species are both contaminated through water pollution, during processing and packaging. The contamination of dried crayfish increases when they are expose to flies, dust and handling with dirty hands in the market.

Crayfish species are contaminated by several microorganisms. These microorganisms are resistant to some antibiotics which can be a major threat to public health(Adenalke et al., 2016).These organisms are mainly enteric bacteria that can colonise gut as resistant commensals or cause gastroenteritis (Adenalke et al., 2016). Some of these organisms are Escherichia coli, Staphylococcus aureus, Bacillus cereus and Salmonella sp.

The aim of this study is to determine the bacteriological quality of dried crayfish of two different types sold at Ogbete main market, Enugu in Enugu State, Nigeria, with the view of highlighting the implications of consuming raw foods.

\section{Materials and Methods}

\section{Sample Collection}

A total of sixty(60) dried crayfish samples (30 each for both sample) were collected from different sellers at Ogbete main market, Enugu. Two kinds of crayfish (Orini and
Ishekeri) sold in the market were labeled as sample A and sample B. Their names are based on the towns where they are harvested. The samples were packed aseptically into two sterile containers and were taken to the Applied Microbiology laboratory at Enugu State University of Science and Technology, Enugu State for microbial identification.

\section{Sample Preparation}

A total of $5 \mathrm{~g}$ each of the sample A and sample $\mathrm{B}$ were weighed into a test tube containing $20 \mathrm{ml}$ of sterile distilled water. This was swirled evenly in order to homogenize the mixture and this was labelled as the stock. A ten-fold dilution of the homogenates was made with sterile normal saline as diluents. This was carried out as described by Cheesebrough (2002). A total of $9 \mathrm{ml}$ of the normal saline was measured into eight test tubes. $1 \mathrm{ml}$ of the stock was collected using a pipette and serially diluted into the first tube and from the first tube to the second test tube up to the eighth test tube respectively $\left(10^{-1}\right.$, $\left.10^{-2}, 10^{-3}, 10^{-4}, 10^{-5}, 10^{-6}, 10^{-7}, 10^{-8}\right)$. Approximately $0.1 \mathrm{ml}$ was taken from dilution $10^{-3}$ and $10^{-4}$ into different sterile agar plates in duplicates. All plates were incubated at $37^{\circ} \mathrm{C}$ for $24 \mathrm{~h}$. After incubation, the bacterial colonies on the agar plates were counted and representative colonies were transferred onto nutrient agar slants for biochemical identification.

\section{Calculations of Colony Forming Unit}

The method described by Collins et al., (1989) for estimating bacterial counts was used to enumerate the total viable counts of the isolates. The number of colonies on the plate was multiplied by the reciprocal of the dilution factor and calculation was for $0.1 \mathrm{ml}$ of the original sample. The mean colony count on the positive growth plates were used to estimate the total count. 
Characterization and Identification of the Isolates

All the organisms isolated were sub-cultured in nutrient agar plates to obtain a pure culture. Gram stain and biochemical tests were carried out to identify the organisms Cheesebrough (2002). The biochemical tests included catalase, coagulase, oxidase, indoleand sugar fermentation tests like lactose, sucrose, mannitol and glucose.

\section{Results and Discussion}

\section{Determination of Bacterial load for two Crayfish types}

Two types of crayfish labelled as sample A and sample B were examined and their bacterial loads were determined. The result is shown in Table 1.

Determination of the Morphology andBiochemical Characteristics of the Bacterial Isolates

Based on Gram stain and biochemical reactions, the isolates were identified as shown in Table 2.

Determination of the Prevalence Rate of Bacteriaon the CrayfishSamples

A total of 60 samples of dried crayfish comprising of 30 samples each for both $\mathrm{A}$ and $\mathrm{B}$ respectively were examined. A total of four (4) different organisms were isolated. Staphylococcus aureus was found to have the highest prevalence rate followed by Escherichia coli, Bacillus sp and Klebsiellasp as shown in Table 3.

Dry crayfish (Astacus leptodactylus) is one of the main protein rich foods. The greatest challenge in this food sample is its contamination by bacteria. This is as a result of exposing it to flies, dust and poor handling by both the sellers and consumers. This present study revealed the bacterial load of the sample with values ranging from $2.1 \mathrm{x}$ $10^{4} \mathrm{cfu} / \mathrm{ml}$ to $2.5 \mathrm{x} 10^{4} \mathrm{cfu} / \mathrm{ml}$ for both samples (Table 1). This study is in agreement with the work done by Kasozi et al., (2016) which shows microbial load of $2.4 \times 10^{4} \mathrm{cfu} / \mathrm{ml}$ to 7.2 x $10^{4} \mathrm{cfu} / \mathrm{ml}$ and Israel et al., (2016) who reported the microbial load of crayfish from $4.2 \mathrm{x} 10^{2} \mathrm{cfu} / \mathrm{g}$ to $4.4 \mathrm{x} 10^{2} \mathrm{cfu} / \mathrm{g}$. This study shows a bacterial growth of $73.33 \%$ and nonbacterial growth of $26.67 \%$ for sample A while $76.67 \%$ for bacterial growth and $23.33 \%$ for non-bacterial growth for sample B.

This shows that 45(75\%) samples collected were contaminated. This could be as a result of the fact that during handling of crayfish, the natural flora of crayfish environment will be contaminated with organisms associated with man, such as Staphylococcus aureus which was isolated in this study. This study revealed the prevalence rate of bacteria as follows: Staphylococcus aureus $30 \%$ and $26.67 \%$, Bacillus species $13.33 \%$ and $16.67 \%$, Escherichia coli $20 \%$ and $20 \%$ and Klebsiella species $10 \%$ and $13.33 \%$ respectively for both samples (Table 3). This study is in agreement with the findings of Israel et al., (2016) who found the presence of bacteria like Staphylococcus aureus, Bacillus subtilis and Escherichia coli. Also this study correlates with the findings of Elsherief et al., (2014) who found $12 \%$ and $8 \%$ of Escherichia coli from both retailed fish and fish farm respectively, the work of Yagoub(2009)who isolated 13\% of Escherichia coli from raw fish and the findings of Yahyazadeh et al., (2016) who isolated $17.14 \%$ of Staphylococcus aureus from crayfish and the work done by Kasozi et al., (2016) who isolated Bacillussp, Staphylococcus aureus and Escherichia coli with the values ranging from $11.11 \%$ to $22.22 \%$. This study revealed $10 \%$ and $13.33 \%$ of Klebsiella species from both samples. 
Table.1Themean bacterial count $(\mathrm{cfu} / \mathrm{ml})$ of the crayfish samples

\begin{tabular}{ll}
\hline Types of Crayfish & Average count $(\mathrm{cfu} / \mathrm{ml})$ \\
\hline Sample A & $2.5 \times 10^{4}$ \\
Sample B & $2.1 \times 10^{4}$ \\
\hline
\end{tabular}

Table.2 Morphological and Biochemical Characteristics of the Bacterial Isolates from crayfish samples

\section{Isolate colony microscopy Gramstain Catalase Coagulase Oxidase IndoleSugar fermentationOrganisms found description Lactose Sucrose MannitolGlucose}

1.Small smooth cocci in $+++\quad-\quad++\quad+\quad+$ Staphylococcussp yellow colonies butches with glistering surface onMannitol salt agar.

2. Raised pinkish Short - - $-{ }_{-} \quad+\quad+\quad+\quad+\quad+\quad+$ Escherichia coli colonies on MacConkey agar.

3.Pale colonies Short $++-\quad-\quad-\quad+\quad+\quad+\quad$ Bacillus $\mathrm{sp}$ rods onMacConkey agar in chains.

4. Colonies Short rods- - - $\quad-\quad+\quad++\quad+\quad$ Klebsiellasp appearedlarger, mucoid and red with diffusing red pigment on MacConkey agar.

Table.3 Prevalence rate of bacteria on the crayfish samples

\section{Types of Number of Bacterial Non Bacillus Staphylococcus Escherichia klebsiellasp CrayfishSampleGrowthBacterial Growthspaureus coli

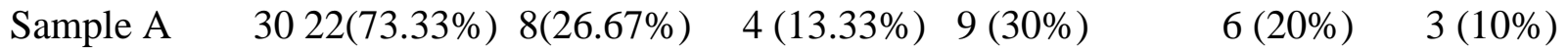 \\ Sample B $\quad 30 \quad 23(76.67 \%) 7(23.33 \%) 5(16.67 \%) \quad 8(26.67 \%) \quad 6(20 \%) \quad 4(13.33 \%)$}


This is not in line with the study of Elsherief et al., (2014) who had $2 \%$ of Klebsiella species from retailed fish. Isolation of these organisms from these samples are due to storage conditions (Sheen et al., 2012) and as well as exposing the food samples to dirty environment, improper handling and poor hygiene by both the sellers and consumers. The higher prevalence (20\%) of Escherichia coli in this study may suggest higher contamination with faecal matter. The increase of food poisoning in our environment is worrisome. It is therefore, imperative that public awareness should be disseminated to both sellers and buyers informing them the impeding danger of poor handling of edible foods.

From this study, contamination of dried crayfish could be due to improper handling, improper storage and dirty environment in which they are sold.

\section{Recommendations}

It is therefore recommended that:

Crayfish should be properly preserved and handled to avoid been contaminated with pathogenic organisms.

Crayfish should be covered to avoid flies on them.

Crayfish should be displayed in a hygienic environment.

Crayfish should be cooked properly before consumption.

\section{References}

Adeleye, O. A. (1992). Conservation needs of fisheries resources and reorientation for sustainable captive and culture practices. Proceedings of the $10^{\text {th }}$ annual conference of the fisheries society of Nigeria (FISON) Lagos, Nigeria, Pp230-234.

Adenaike, O., Olonitola, O. S., Ameh, J. B. and Whong, C. M. Z. (2016). Multidrug Resistance and Multiple Antibiotic Resistance index of Escherichia coli strains isolated from retailed smoked fish. Journal of Natural Sciences Research, 6(9): 7-10.

Cheesbrough,M. (2002). District Laboratory practice in tropical countries. Part II, Cambridge University press Pp136142.

Collins, C. H., Iyne, P. M. and Grange, G. M. (1989). Identification of bacteria In: Microbiological Methods, $6^{\text {th }}$ edition Butterworth, London press Pp64-76.

Elsherief, M. F., Mousa, M. M., El- Galil, H. A. and El-Bahy, F. (2014). Enterobacteriaceae Associated with farm fish and Retailed ones. Alexandria Journal of Veterinary Sciences, 42: 99-104.

Israel, D. U., Inana, M. E., Adindu, M. N. and Akanide, S. A. (2016). Mycoflora, Proteolytic Potential and quality implication of Dried crayfish at Uyo Urban market, Uyo,Nigeria. Food Science and Quality Management, 47: 48-54.

Kasozi, N., Namulawa, V. T., Dega, G. I., Kato, C. D. and Mukalazi, J. (2016). Bacteriological Physicochemical qualities of traditionally dry-salted Pebby (Aletesbaremoze) sold in different markets of West Nile Region in Uganda. African Journal of Microbiology Research, 10(27): 10241030.

Nyenye, M. E., Odjadjare, C. E., Tanih, N. E., Green, E. and Ndip, R. N. (2012). Food borne pathogens Recovered from Ready to eat foods from roadside cafeterias and retail outlets in Alice Eastern Cape province, South Africa: 
Public Health Implications.

International Journal of Environmental Research and Public Health, 9(8): 2608-2619.

Orogu, J.O., Aphair, A. E. and Oghonyon, E. I.(2018). Bacteriological Analysis of Dried Crayfish and Stockfish in Ozoro Market. Indo American Journal of Pharmaceutical Sciences, 5(6): 52345239.

Sheen, S., Huang, L. and Sommers, C. (2012). Survival of Listeria monocytogenes, Escherichia coli 0157:H7 and Salmonellaspp on catfish fillets exposed to microwave heating in a continuous mode. Journal of Food
Science, 77(8): 209-214.

Willard, H. H. (2006). Instrumental Method of Analysis Van Nostrand Co. New York Pp 208.

Yagoub, S. O.(2009). Isolation of Enterobacteriaceae and Pseudomonasspp from raw fish sold in fish market in Ichartoum State. Journal of Bacteriological Research, 1(7): 8588.

Yahyazadeh, M. Y., Seidgar, M. and Shiri, S. (2016). Isolation and Characterization of different bacterial agents from Crayfish (Astacus leptodactylus) of Aras reservoir, Iran. Iranian Journal of Aquatic Animal Health, 2(1); 80-86.

\section{How to cite this article:}

Ugwu, Celestina Chibuzo 2019. Evaluation of Bacteriological Quality of Dried Cray fish (Astacus leptodactylus) Sold at Ogbete Main Market in Enugu Metropolis, Nigeria. Int.J.Curr.Microbiol.App.Sci. 8(09): 2643- 2648.doi: https://doi.org/10.20546/ijcmas.2019.809.305 